\title{
Compost offers high economic return
}

Supplying sufficient nitrogen to the plant is a primary concern for organic vegetable growers. They often plant cover

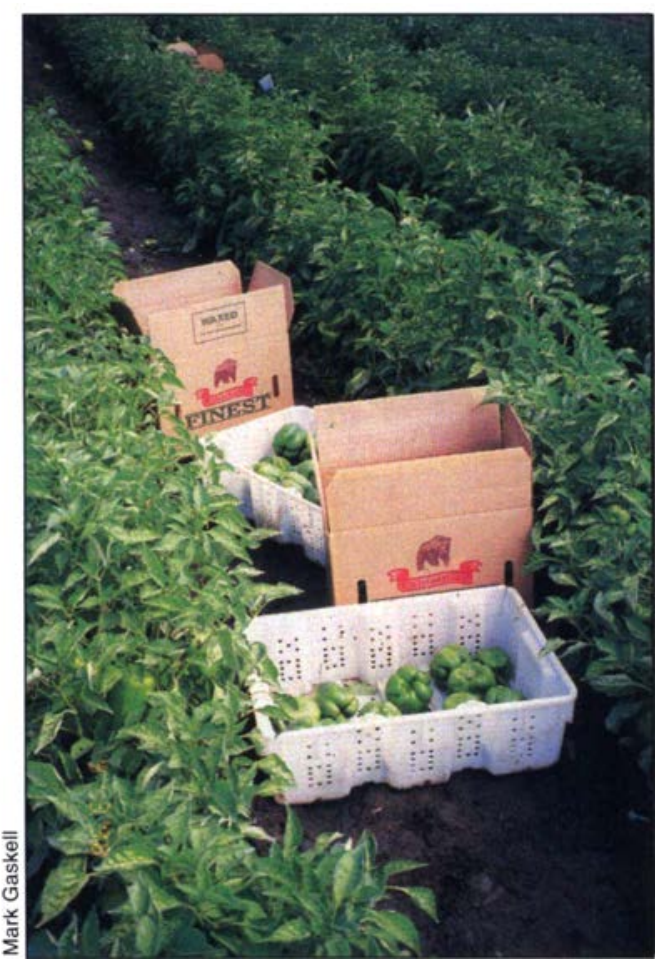

Seven different organic fertilizers were compared on bell peppers. crops or apply organic fertilizers to boost the soil's nitrogen content.

To compare their benefits, Santa Barbara County farm advisor Mark Gaskell tested several different organic fertilizers on sprinkler-irrigated bell peppers over 16 weeks of the 1998 growing season. The trial was conducted at Nojoqui Farm, a certified organic farm near Buellton.

Gaskell compared compost, pelleted chicken manure, fish meal, liquid fish, liquid soybean meal, feather meal and seabird guano. The fertilizers were applied once before the bell peppers were transplanted, then three times after planting.

He found that the different fertilizers did not affect total pepper yield as much as they influenced early yield and size. The earliest yield and largest peppers were observed in the plots treated with feather meal at the highest rate -180 pounds of nitrogen per acre. However, the highest economic return per fertilizer dollar was in the plots treated with compost at the rate of 180 pounds of nitrogen per acre.

The highest early yields and largest peppers tended to come from plots treated with fish meal, liquid fish, liquid soybean meal, feather meal and seabird guano, all of which had shown higher weekly peak soil nitrate nitrogen.

Compost and pelleted chicken manure, which consistently had the lowest soil nitrate nitrogen levels even at the highest rates, produced fewer peppers than the other plots. The feather meal fertilizer produced larger peppers and a greater early yield, two characteristics that draw a price premium. However, because compost is much less expensive than the other fertilizers, it turned out to be the most economical.

"The economic value of a fertilizer material may depend more on cost per unit of nitrogen than the nitrogen mineralization associated with the material," Gaskell says.

He cautions growers that the cost and quality of compost varies with its composition, "It is unclear whether compost can be managed to attain the levels of soil nitrate nitrogen apparently necessary for optimum bell pepper yield and size," Gaskell says. He found that soil nitrate nitrogen peaks 3 to 4 weeks following application of organic fertilizers, then returns to preapplication levels. Organic fertilizer materials do not offer a slow release of nitrogen to the crop; they need to be managed like soluble fertilizers.

Because the highest yields were harvested from the plots treated with the trial's top rate of fertilizer, Gaskell suggests that rates higher than 180 pounds of nitrogen per acre may further increase bell pepper yields.

\section{Radio reaches Hmong farmers}

After the Vietnam War, about 300,000 Hmong, Mien and Lao political refugees came to the United States, including 35,000 Hmong who settled in Fresno County. Known as the "mountain people" of Laos, the Fresno County community represents the largest single concentration of Hmong in the United States.
About 630 of Fresno County's Hmong are small farmers. Although many were farmers in Laos, they often find that the practices they learned there are not applicable in California. They often possess limited English language skills, according to Fresno County small farms advisor Richard Molinar. 